Journal Indonesian Language Education and Literature Vol. 2, No. 1, 2016

http://www.syekhnurjati.ac.id/jurnal/index.php/jeill/

\title{
CHARACTER BUILDING ANAK USIA DINI MELALUI OPTIMALISASI FUNGSI PERMAINAN TRADISIONAL BERBASIS BUDAYA LOKAL
}

\author{
Rifa Suci Wulandari dan Hestri Hurustyanti \\ STKIP PGRI Ponorogo \\ meilanty_06@yahoo.co.id
}

\begin{abstract}
Abstrak
Tujuan penelitian ini adalah mengetahui pelaksanaan permainan tradisional berbasis budaya lokal dalam mendukung pengembangan karakter kejujuran serta faktor pendukung dan penghambatnya di TK Pancasila. Peneliti menggunakan jenis penelitian deskriptif kualitatif. Analisis yang dipakai dalam penelitian ini adalah analisis kualitatif melalui beberapa tahapan sebagai berikut: (1) Pengumpulan data yang dilakukan melalui observasi, wawancara, dan tes skala sikap, (2) Reduksi data, (3) Penyajian data, dan (4) Penarikan kesimpulan dan verifikasi. Hasil penelitian menunjukkan bahwa tahapan pelaksanaan permainan tradisional di TK Pancasila meliputi: (1) Tahap perencanaan, (2) Tahap pelaksanaan kegiatan permainan tradisional yang terdiri dari tiga kegiatan yaitu kegiatan pembuka, kegiatan inti dan penutup, (3) Tahap Evaluasi. Dari hasil pretest dan posttest dapat disimpulkan bahwa hasil permainan tradisional dalam mendukung pengembangan karakter kejujuran anak usia dini di TK. Pancasila adalah perubahan dalam kepribadian individu yang ditampakkan dalam bentuk peningkatan kualitas karakter kejujuran sebagai akibat dari proses belajar yang diperoleh dari pengalaman bermain permainan tradisional. Faktor pendukung dalam pelaksanaan kegiatan bermain permainan tradisional di TK. Pancasila meliputi: (1) Kurikulum yang terstruktur, (2) Adanya motivasi bermain dolanan dari peserta didik yang cukup tinggi, (3) Fasilitas dan lingkungan yang cukup memadai mendukung untuk proses pelaksanaan permainan tradisional. Sedangkan faktor penghambatnya antara lain: (1) Konsentrasi anak yang mudah berubah-ubah, (2) Kurangnya waktu yang digunakan untuk kegiatan permainan tradisional, (3) Keterbatasan pengetahuan pendidik mengenai jenis permainan tradisional yang dapat digunakan dalam pembelajaran khususnya untuk meningkatkan pengembangkan karakter kejujuran anak usia dini.
\end{abstract}

Kata Kunci: permainan tradisional, karakter kejujuran, anak usia dini

\begin{abstract}
This research aims to know the application of traditional games based on local culture to develop honesty character and its supporting and obstructing factors at TK Pancasila. The researcher used qualitative descriptive research. The research analysis used was qualitative analysis using the following steps: (1) Collecting the data through observation, interview, and attitude scale test, (2) Reducing the data, (3) Presenting the data, and (4) Concluding and verifying. The research result at TK Pancasila showed that the stages of traditional games application included: (1) Planning stage, (2) Applying traditional games stage in three activities (opening, main activity and closing), and (3) Evaluating stage. The result from pretest and posttest can be concluded that the result of traditional games in developing honesty character for young learners at TK Pancasila
\end{abstract}




\section{Journal Indonesian Language Education and Literature Vol. 2, No. 1, 2016 \\ http://www.syekhnurjati.ac.id/jurnal/index.php/jeill/}

was the changing of individual character shown from the increase of honesty character quality as the effect of learning process from experience in playing traditional games. The supporting factors of applying traditional games at TK Pancasila included: (1) Structured curriculum, (2) Fairly high playing motivation from young learners, (3) Conducive facilities and environment to support the process of applying traditional games. The obstructing factors included: (1) The unstable young learners concentration,

(2) The minimum time used for traditional games activity, (3) Limited knowledge from teachers about kinds of traditional games used in teaching especially to improve honesty character development from young learners.

Kata Kunci: traditional games, honesty character, young learners

\section{A. Pendahuluan}

Eksistensi suatu bangsa sangat ditentukan oleh karakter yang dimiliki. Hanya bangsa yang memiliki karakter kuat yang mampu menjadikan dirinya sebagai bangsa yang bermartabat dan disegani oleh bangsa-bangsa lain. Bangsa yang ingin maju, berdaulat, dan sejahtera membutuhkan karakter yang kuat. Oleh karena itu, pendidikan karakter perlu menjadi perhatian yang serius dan utama dalam kehidupan berbangsa dan bernegara. Persoalan karakter bangsa merupakan isu yang mengemuka di masyarakat saat ini. Korupsi, tindakan asusila, kekerasan, perkelahian massa, pelanggaran hak asasi manusia, pencurian, pembunuhan, kehidupan ekonomi yang konsumtif serta kehidupan politik yang tidak produktif adalah sebagian kecil dari kasus terkait moralitas bangsa. Fenomena tersebut adalah sebagian kecil dari sekian banyak indikasi menurunnya kualitas karakter bangsa.

Krisis karakter tidak hanya terjadi di kalangan masyarakat awam, tetapi juga sudah merambah ke kalangan professional, tokoh masyarakat, para terpelajar, para pendidik, elit politik, bahkan hingga para pemimpin bangsa dan negara. Melihat hal tersebut sebenarnya ada jalan keluar yang mampu menjadi solusi yang tepat untuk permasalahan ini. Solusi yang paling tepat untuk masalah ini adalah dengan membangun dan menata kembali karakter dan watak bangsa kita sendiri. Upaya yang tepat untuk membangun dan mengembangkan karakter manusia dan bangsa Indonesia agar memiliki karakter yang baik, unggul dan mulia adalah melalui jalur pendidikan, karena pendidikan memiliki peran penting dan sentral dalam pengembangan potensi manusia, termasuk potensi mental. Melalui pendidikan diharapkan terjadi transformasi yang dapat 


\section{Journal Indonesian Language Education and Literature Vol. 2, No. 1, 2016 http://www.syekhnurjati.ac.id/jurnal/index.php/jeill/}

menumbuh kembangkan karakter positif, serta mengubah watak dari yang tidak baik menjadi baik.

Indonesia dikenal memiliki kekayaan ragam budaya yang luhur. Budaya tersebut adalah harta kekayaan bangsa Indonesia yang harus dilestarikan keberadaannya. Nilainilai budaya lokal terdapat pada berbagai fenomena budaya masyarakat. Salah satunya ada pada permainan tradisional anak. Permainan tradisional memiliki arti tersendiri dalam menanamkan sikap, perilaku, dan keterampilan pada anak. Ada makna yang luhur yang terkandung di dalamnya, seperti nilai agama, nilai edukatif, norma, dan etika yang kesemuannya itu akan bermanfaat dalam kehidupan bermasyarakat kelak.

Membangun karakter bukanlah merupakan produk instant yang dapat langsung dirasakan sesaat setelah pendidikan tersebut diberikan. Pendidikan karakter merupakan proses panjang yang harus dimulai sejak dini pada anak-anak dan baru akan dirasakan setelah anak-anak tersebut tumbuh menjadi dewasa. Penanaman pondasi karakter kejujuran harus ditanamkan sejak usia dini. Salah satu cara untuk menanamkan karakter kejujuran pada anak adalah melalui pendidikan di sekolah. Menurut Schweinhart (1994) dalam Megawangi (2004) pendidikan karakter di sekolah hendaknya dimulai dari usia TK. Pembelajaran bagi anak usia dini hendaknya dilakukan secara bertahap. Dalam membangun karakter kejujuran pada anak, terlebih dahulu harus dikenalkan konsep atau pemahaman kepada anak usia dini tentang karakter kejujuran.

Model pendidikan untuk anak usia dini harus disesuaikan dengan masa perkembangan mereka yang masih didominasi oleh permainan sebagai media transfer pengetahuan. Salah satu metode yang sesuai digunakan dalam implementasi pendidikan membangun karakter kejujuran adalah melalui bermain. Bermain adalah suatu kebutuhan yang sudah ada dengan sendirinya (inhernt), dan sudah terberi secara alami. Permainan yang bisa digunakan adalah permainan tradisional anak yang sudah cukup lama berkembang di negeri ini, bahkan permainan-permainan tersebut sarat dengan nilai-nilai budaya bangsa. Namun demikian, seiring dengan perkembangan zaman permainan tradisional ini semakin lama semakin dilupakan oleh anak-anak terutama di perkotaan karena sudah semakin banyaknya permainan modern yang berasal dari luar negeri.

Permainan tradisional anak merupakan unsur-unsur kebudayaan yang tidak dapat dianggap remeh, karena permainan ini memberikan pengaruh yang tidak kecil terhadap perkembangan kejiwaan, sifat, dan kehidupan sosial anak di kemudian hari. Selain itu, 


\section{Journal Indonesian Language Education and Literature Vol. 2, No. 1, 2016 \\ http://www.syekhnurjati.ac.id/jurnal/index.php/jeill/}

permainan anak-anak ini juga dianggap sebagai salah satu unsur kebudayaan yang memberi ciri atau warna khas tertentu pada suatu kebudayaan. Oleh karena itu, permainan tradisional anak-anak juga dapat dianggap sebagai aset budaya, sebagai modal bagi suatu masyarakat untuk mempertahankan keberadaannya dan identitasnya di tangah kumpulan masyarakat yang lain (Sukirman, 2004).

Menurut Purwaningsih (2006) permainan tradisional mengandung unsur-unsur nilai budaya. Menurut Dharmamulya (2008), unsur-unsur nilai budaya yang terkandung dalam permainan tradisional adalah nilai kesenangan atau kegembiraan, nilai kebebasan, rasa berteman, nilai demokrasi, nilai kepemimpinan, rasa tanggung jawab, nilai kebersamaan dan saling membantu, nilai kepatuhan, melatih cakap dalam berhitung, melatih kecakapan berpikir, nilai kejujuran dan sportivitas.

Berdasarkan uraian di atas, maka penelitian ini bertujuan untuk mengetahui pelaksanaan permainan tradisional berbasis budaya lokal dalam mendukung pengembangan karakter kejujuran di TK Pancasila serta faktor pendukung dan penghambat pelaksanaan permainan tradisional tersebut.

\section{B. Metode Penelitian}

Jenis penelitian yang digunakan adalah penelitian deskriptif kualitatif. Dalam menentukan subjek penelitian ini dilakukan teknik purposive yaitu pengambilan sumber data didasarkan atas adanya tujuan tertentu yang menjadi fokus penelitian dan juga tidak mempersoalkan tentang ukuran dan jumlah dalam pengambilan sumber data atau subjek penelitian (Arikunto, 2010:183). Subjek dalam penelitian ini adalah pendidik dan peserta didik TK. Pancasila, Desa Kauman, Kecamatan Kauman, Kabupaten Ponorogo. Teknik pengumpulan data yang digunakan oleh peneliti untuk memperoleh data yang diperlukan dalam penelitian ini adalah observasi (pengamatan), wawancara, dan tes skala sikap.

Teknik analisis data yang digunakan dalam penelitian ini dimulai dari seluruh data yang terkumpul dari pengamatan, wawancara, dan tes skala sikap. Aktivitas dalam analisis data kualitatif dilakukan secara interaktif dan berlangsung secara terus menerus sampai tuntas. Hal ini dikarenakan proses analisis data kualitatif berlangsung selama dan pasca pengumpulan data. Analisis yang dipakai untuk menganalisa data dalam penelitian ini adalah analisis kualitatif yaitu: (1) Pengumpulan data, (2) Reduksi data, (3) Penyajian data, dan (4) Penarikan kesimpulan dan verifikasi. 


\section{Hasil Dan Pembahasan}

\section{Pelaksanaan Permainan Tradisional dalam Mendukung Pengembangan}

\section{Karakter Kejujuran di TK Pancasila}

Dari penelitian yang dilakukan diketahui bahwa kegiatan permainan tradisional mendukung peserta didik mengembangkan karakter kejujuran melalui proses belajar dari pengalaman yang diperoleh saat bermain. Berdasarkan hasil penelitian di TK Pancasila, pelaksanaan permainan tradisional dalam mendukung pengembangan karakter kejujuran anak usia dini meliputi beberapa tahap perencanaan, proses pelaksanaan, dan evaluasi.

\section{a. Perencanaan}

Dari hasil penelitian yang dilakukan diketahui bahwa perencanaan program kegiatan pembelajaran adalah langkah awal yang harus dilakukan sebelum proses pembelajaran dilaksanakan. Perencanaan pembelajaran dengan permainan tradisional di TK Pancasila yaitu dengan mengembangkan kurikulum berdasarkan panduan pengembangan kurikulum PAUD berbasis budaya lokal yang meliputi perencanaan tahunan (PROTA), perencanaan program semester (PROMES), hingga penyusunan rencana kegiatan mingguan (RKM) dan rencana kegiatanharian (RKH) menyesuaikan dengan tema dan indikator yang akan dikembangkan, kelompok umur, kebutuhan, minat dan karakteristik anak

Persiapan jenis permainan tradisional dalam pembelajaran anak usia dini dilakukan oleh peneliti dan pendidik dengan menyiapkan materi (konten) dan proses belajar. Persiapan jenis-jenis permainan dilakukan oleh pendidik yaitu dengan menentukan beberapa macam permainan tradisional yang akan digunakan dalam pembelajaran. Beberapa jenis permainan tradisional seperti Dhakon, Cublak-Cublak Suweng, Jamuran dan Petak Umpet dipilih oleh peneliti dan pendidik untuk dimasukkan ke dalam rencana kegiatan pembelajaran karena permainan-permainan tradisional tersebut menunjukan indikator perkembangan anak yang mampu meningkatkan perkembangan karakter kejujuran anak.

\section{b. Pelaksanaan kegiatan permainan tradisional}

Dari hasil penelitian, pelaksanaan kegiatan pembelajaran dengan permainan tradisional dilakukan dalam beberapa pijakan yang berisi sejumlah pengalaman belajar peserta didik melalui bermain yang diberikan pada anak usia dini 
berdasarkan potensi dan tugas perkembangan yang harus dikuasainya dalam rangka pencapaian kompetensi yang harus dimiliki anak. Kegiatan permainan dilakukan dalam kelompok kecil, dan kelompok besar meliputi tiga kegiatan pokok, yaitu kegiatan pembukaan, kegiatan inti dan kegiatan penutup.

Dari hasil pengamatan diketahui pelaksanaan permainan tradisional mencakup:

1) Kegiatan pembuka

a) Senam sehat ceria dengan musik atau senam sendiri tanpa musik

b) Bermain dalam lingkaran dengan lagu-lagu dolanan

c) Baris untuk berdoa dengan dipimpin oleh salah satu peserta didik di depan.

d) Hafalan surat pendek dan doa sehari-hari

2) Kegiatan inti

a) Pijakan sebelum main

Kegiatan diawali dengan duduk melingkar atau berdiri melingkar untuk kegiatan berdoa, membaca surat-surat pendek seperti Al-Fatikhah, AlFalaq, membaca doa sehari-hari, selanjutnya salam sapa sekaligus presensi yang dilakukan dengan bersama-sama untuk mengetahui siapa saja teman yang tidak hadir. Selanjutnya, pendidik terlebih dahulu menjelaskan tema dan kosakata sebagai cara untuk memperkenalkan katakata baru dan menambah perbendaharaan kata pada peserta didik, serta menjelaskan jenis permainan beserta aturan permainan yang akan dilakukan dan disepakati oleh semua peserta didik.

b) Pijakan Saat Main

Pendidik berkeliling di antara peserta didik yang sedang bermain dan pendidik memberikan penilaian observasi, serta pendidik memberikan pujian terhadap pekerjaan peserta didik.

c) Pijakan setelah main

Pendidik mengajak peserta didik bernyanyi lagu-lagu dolanan untuk menambah semangat peserta didik atau yang disebut dengan kegiatan refreshing setelah kegiatan permainan selesai. Kemudian dilanjutkan dalam barisan atau lingkaran untuk melakukan recalling dengan menanyakan kegiatan apa saja yang dilakukan, jenis permainan apa yang 
Journal Indonesian Language Education and Literature Vol. 2, No. 1, 2016

http://www.syekhnurjati.ac.id/jurnal/index.php/jeill/

dilakukan dan tujuan dari permainan, hingga menanyakan hal-halyang dihadapi peserta didik dalam bermain, hal ini untuk melatih anak agar dapat dalam menyelesaikan masalah. Selanjutnya, berdoa selesai belajar untuk mengakhiri kegiatan bermain. Peserta didik mengekhiri pembelajaran dengan cara menjawab pertanyaan dengan atau permainan yang diberikan pendidik untuk melatih keberanian peserta didik seperti bernyanyi, tebak-tebakan sehingga dengan tertib anak berpamitan dengan bersalaman tanpa berebut.

\section{3) Kegiatan Penutup}

Berdoa pulang dan salam.

\section{c. Evaluasi}

Teknik penilaian yang digunakan dalam penelitian ini adalah observasi, interview dan tes skala sikap menggunakan soal cerita. Kondisi setiap peserta didik dalam pelaksanaan kegiatan permainan tradisional berbeda-beda antara satu sama lain, hal ini dipengaruhi tingkat konsentrasi yang sering berubah-ubah dan tingkat pencapaian masing-masing peserta didik.

Hasil pretest menunjukkan bahwa terdapat anak yang belum cukup memahami tentang karakter kejujuran. Misalnya, pada sebuah cerita yang menceritakan tentang seorang anak yang menemukan barang di sekolah, apa yang akan dilakukan? Anak tersebut dengan jelas mengatakan bahwa dia akan mengambil barang tersebut dan tidak dikembalikan. Pada cerita tentang anak yang sedang bermain di sekolah, kemudian temannya ingin ikut bermain, Ada anak yang mengatakan bahwa itu adalah tindakan yang wajar dan boleh dilakukan, karena dia menganggap bahwa siapa yang mengambil mainan duluan, maka dia yang menggunakannya. Tapi sebagian besar anak juga sudah cukup mengerti tentang karakter kejujuran. Misalnya pada cerita seorang anak yang menemukan barang di sekolah, apa yang akan dilakukan?, ada anak yang berkata bahwa tidak boleh diambil karena bukan miliknya. Terdapat pula anak yang sangat mengerti dan bisa menjelaskan apa yang bisa dia lakukan misalnya apabila dia menemukan barang maka harus dikembalikan kepada pemiliknya.

Hasil postest menunjukkan bahwa sebagian besar anak mengerti karakter kejujuran. Anak yang pada saat pretest menunjukkan jawaban belum mengerti 
dari cerita yang ada, pada saat posttest sebagian besar cukup mengerti dan sangat mengerti tentang karakter kejujuran. Anak-anak belajar memahami nilai-nilai karakter kejujuran dengan gembira yaitu melalui permainan tradisional. Sesuatu yang dilakukan dengan gembira itu lebih mudah di terima oleh anak. Gembira biasanya ditandai dengan tertawa. Hampir setiap permainan tradisional dilakukan dengan banyak orang atau berkelompok sehingga anak harus bisa bersosialisasi dengan temannya.

Seperti yang telah dijelaskan di atas bahwa permainan tradisional bisa menjadi salah satu media dalam mengembangkan karakter kejujuran pada anak di sekolah. Sekolah adalah tempat yang sangat strategis untuk pendidikan karakter karena anak-anak dari semua lapisan akan mengenyam pendidikan di sekolah, selain itu anak-anak menghabiskan sebagian besar waktunya di sekolah, sehingga yang didapatkannya di sekolah akan mempengaruhi pembentukan karakternya.

Dalam penelitian ini banyak sekali nilai-nilai yang ada dalam permainan tradisional yaitu jiwa kepemimpinan, kerjasama, lapang dada, menegakkan keadilan, taat aturan, jujur, usaha keras, tidak sombong, cerdik, dan motivator untuk menang. Salah satu contoh misalnya permainan tradisional dhakon mengandung nilai disiplin diri, kejujuran diri, kerja sama, menghargai kawan dan lawan, kecepatan dan ketepatan, melatih kesabaran, tanggung jawab.

Berdasarkan uraian di atas dapat disimpulkan bahwa penggunaan permainan tradisional jawa merupakan suatu metode pembelajaran yang bisa digunakan untuk mengembangkan karakter kejujuran pada anak usia dini.

\section{Hasil Permainan Tradisional dalam Mendukung Pengembangan Karakter Kejujuran Anak Usia Dini}

Dari hasil pretest dan posttest dapat disimpulkan bahwa hasil permainan tradisional dalam mendukung pengembangan karakter kejujuran anak usia dini di TK Pancasila adalah perubahan dalam kepribadian individu yang ditampakkan dalam bentuk peningkatan kualitas karakter kejujuran. Pengembangan karakter kejujuran tersebut kaitannya dengan perubahan kualitas sebagai akibat dari proses belajar yang diperoleh dari pengalaman bermain permainan tradisional Dhakon, Jamuran, 
Journal Indonesian Language Education and Literature Vol. 2, No. 1, 2016

http://www.syekhnurjati.ac.id/jurnal/index.php/jeill/

Cublak-Cublak Suweng, dan Petak Umpet yang didukung juga oleh faktor lingkungan dimana peserta didik bermain.

\section{Faktor Pendukung dan Penghambat Pelaksanaan Permainan Tradisional}

\section{a. Faktor Pendukung}

Faktor pendukung dalam setiap kegiatan merupakan suatu kekuatan dalam melaksanakan kegiatan yang telah direncanakan. Adapun faktor yang mendukung antara lain:

1) Kurikulum yang terstruktur dalam membantu pendidik menyiapkan kegiatan permainan tradisional.

2) Adanya motivasi bermain permainan tradisional atau dolanan anak dari peserta didik yang cukup tinggi.

3) Fasilitas dan lingkungan yang cukup memadai mendukung untuk proses pelaksanaan permainan tradisional.

\section{b. Faktor Penghambat}

Adapun faktor-faktor yang menghambat dalam pelaksanaan kegiatan antara lain:

1) Perbedaan tingkat konsentrasi pada anak usia dini yang mudah berubah-ubah.

2) Kurangnya waktu yang digunakan untuk pelaksanaan kegiatan permainan tradisonal.

3) Keterbatasan pengetahuan pendidik tentang jenis permainan tradisional yang dapat diaplikasikan dalam pembelajaran dengan permainan tradisional.

\section{Simpulan}

Kegiatan permainan tradisional anak yang dilaksanakan di TK. Pancasila dalam proses pengelolaan kegiatannya diselenggarakan dengan tujuan untuk memberikan pendidikan karakter kepada anak usia dini melalui kegiatan bermain. Proses pengelolaan permainan tradisional dalam meningkatkan pengembangan karakter kejujuran anak usia dini TK. Pancasila meliputi: (1) Tahap perencanaan, (2) Tahap pelaksanaan kegiatan permainan tradisional yang terdiri dari tiga kegiatan yaitu kegiatan pembuka, kegiatan inti dan kegiatan penutup, (3) Tahap evaluasi yang meliputi observasi, interview, dan tes skala sikap dalam bentuk soal cerita. Dari hasil pretest dan posttest dapat disimpulkan bahwa hasil permainan tradisional dalam mendukung pengembangan karakter kejujuran 
anak usia dini di TK Pancasila adalah perubahan dalam kepribadian individu yang ditampakkan dalam bentuk peningkatan kualitas karakter kejujuran. Pengembangan karakter kejujuran tersebut kaitannya dengan perubahan kualitas sebagai akibat dari proses belajar yang diperoleh dari pengalaman bermain permainan tradisional yang didukung juga oleh faktor lingkungan tempat peserta didik bermain. Faktor pendukung dalam pelaksanaan kegiatan bermain permainan tradisional di TK. Pancasila meliputi: (1) Kurikulum yang terstruktur dalam membantu pendidik menyiapkan permainan tradisional yang disesuaikan dengan RKH, (2) Adanya motivasi bermain dolanan dari peserta didik yang cukup tinggi, dan (3) Fasilitas dan lingkungan yang cukup memadai mendukung untuk proses pelaksanaan permainan tradisional. Sedangkan faktor penghambatnya antara lain: (1) Konsentrasi anak yang mudah berubah-ubah, (2) Kurangnya waktu yang digunakan untuk kegiatan permainan tradisional, dan (3) Keterbatasan pengetahuan pendidik mengenai jenis permainan tradisional yang dapat digunakan dalam pembelajaran khususnya untuk meningkatkan pengembangkan karakter kejujuran anak usia dini.

\section{Daftar Pustaka}

Arikunto, Suharsimi. 2010. Prosedur Penelitian. Jakarta: PT Rineka Cipta.

Dharmamulya, Sukirman. 2008. Permainan Tradisional Jawa. Yogyakarta: Kepel Press.

Direktorat Pembinaan Pendidikan Anak Usia Dini. 2012. Mengenal pendidikan anak usia dini di Indonesia. Diakses dari http://paud.kemdiknas.go.id. Pada hari Senin, 27 Juli 2016, Jam 11.00 WIB.

Megawangi, Ratna. 2004. Pendidikan Karakter. Jakarta: Indonesia Heritage Foundation.

Purwaningsih, Ernawati. 2006. Permainan Tradisional Anak: Salah Satu Khasanah Budaya yang Perlu Dilestarikan. Yogyakarta: Proyek P3NB.

Sukirman, dkk. 2004. Permainan Tradisional Jawa. Kepel Press, Yogyakarta. 